\title{
Peasant Activism and the Rise of Food Sovereignty: Decolonising and Democratising Norm Diffusion?
}

\author{
Dr Robin Dunford, University of Brighton
}

"This is an Accepted Manuscript of an article published by Sage in European Journal of International Relations on 04/11/2015, available online http://ejt.sagepub.com/content/early/2015/11/04/1354066115614382.abstract

\begin{abstract}
'Food sovereignty' emerged from grassroots peasant mobilisations, and has been spread globally by a democratically organised social movement, la Via Campesina. This process has seen food sovereignty influence global political discourse, transform national constitutions and be incorporated into a proposed United Nations declaration on the rights of peasants and other people working in rural areas. By examining the role of grassroots actors in the global South in the construction of this emerging global norm, I militate against tendencies of Westcentrism and elitism in existing literature on the contemporary diffusion of norms. By also discussing the potential marginalisation of grassroots peasant voices in recent United Nations discussions, I suggest that these elitist and West-centric tendencies may also exist in the norm diffusion process itself.
\end{abstract}

\section{Democracy Eurocentrism human rights norms resistance United Nations}

'Food sovereignty', a collective right of peoples to produce their own food in their own territory, emerged from grassroots peasant mobilisations and has been spread globally by a range of actors including la Vía Campesina (LVC), a democratically organised peasant movement. Thanks to the work of peasant activists, food sovereignty has influenced global political discourse, shaped national constitutions and been incorporated into a proposed United Nations (UN) declaration on the rights of peasants and other people working in rural areas. I focus here on grassroots peasant activism in order to counter tendencies of westcentrism and elitism within scholarship on norm diffusion. Within International Relations, norm diffusion scholarship has dominated accounts of how normative ideas including human rights travel. This approach highlights the promotion, by transnational actors, of values that shape the agendas and identities of states and international institutions (Finnemore and Sikkink, 1998). Studies of norm diffusion take for granted the universal nature of 'good', 'liberal' norms before exploring how they spread across the world from a purported origin in the west (Zwingel, 2012, 116). Norm diffusion scholarship thus presents a west-centric story in which western values are the 'normative referent in world politics' (Hobson, 2012, 1). This story of norm diffusion also exhibits elitist tendencies insofar as international institutions, regional organisations or actors with a formal platform within such institutions (including large non-governmental organisations (NGOs) and individual norm-entrepreneurs) are identified as the agents working to diffuse global norms. Little attention is paid to the work of 
grassroots activists - actors who lack such a formal institutional platform - in the construction and diffusion of norms.

By focussing on peasant activism I highlight the key role that grassroots and southern actors have played in the construction and diffusion of food sovereignty. But tracking further the rise of food sovereignty shows that elite agents including state representatives have instigated changes to the meaning of food sovereignty, replacing collective rights to reject a globalised industrial food system with individual rights to choose. As food sovereignty is moving through the UN system, elite actors are therefore marginalising the novel demands made by peasant actors in favour of an affirmation of existing liberal and individual rights. This indicates that elitist and west-centric tendencies in norm diffusion scholarship may reflect similar tendencies in the norm diffusion process. Through its methodology of analysing discussions within international organisations, norm diffusion scholarship fails to recognise this marginalisation of grassroots and southern voices, and therefore risks reproducing these elitist and west-centric tendencies. Mitigating tendencies toward elitism and west-centrism in norm diffusion scholarship can be achieved through a methodological shift, instigated here, of looking beyond the trail of communication developed in high-level institutional discussions and analysing in addition the emergence of norms in and the spread of norms across grassroots mobilisations. Further democratising and decolonising the process through which norms are embedded in the UN, however, will require changes in the receptivity of the UN to grassroots voices.

I begin by arguing that west-centrism and elitism remain in literature on the localisation, vernacularisation and non-western authorship of global norms (Acharya, 2004; Levitt and Merry, 2009; Bettiza and Dionigi, 2014). I then discuss the construction of food sovereignty in grassroots mobilisations, including mobilisations in the global south, before exploring how food sovereignty has travelled across global society through inter-cultural dialogue. This dialogue has generated a norm that has global significance despite emerging from diverse perspectives. Finally, I analyse UN discussions concerning food sovereignty and peasants' rights, suggesting that elite agents may be marginalising the influence of southern and grassroots voices by prompting changes to the meaning of food sovereignty. Revealing the erasure of peasant voices in UN discussions enables me to take a position that is critical of, rather than complicit with, elitist and west-centric tendencies in the norm diffusion process. 


\section{West-centrism and elitism}

In this section, I argue that attention within norm diffusion scholarship to local, vernacular and non-western sources of norms maintains elitist and west-centric tendencies, and therefore does not suffice to decolonise and democratise literature on norm diffusion. I begin by introducing the notion of 'coloniality' before showing how epistemic forms of coloniality remain in literature on the localisation, vernacularisation and non-western authorship of norms. I then reflect on what it means to 'decolonise' and 'democratise' in order to highlight how my subsequent case study can begin to decolonise and democratise norm diffusion scholarship.

Coloniality refers to the 'heterogeneous global hierarchies' that emerged through colonial encounters starting with the 'discovery' of Latin America in 1492 (Grosfoguel, 2009, 18; Mignolo, 2007). Colonial encounters produced a world system marked by intersecting and entangled hierarchies which have persisted after formal colonial rule be it through development, loan conditionalities, or democracy promotion (Escobar, 2012; Grosfoguel, 2009). These hierarchies include class hierarchies, with people from the colonial world occupying lower ends of the labour market, an international division of labour which splits a core area producing high value added goods from a periphery from which resources are extracted, a military inter-state hierarchy through which core states underwrite their economic and epistemic power with military power, and, importantly for my purposes here, epistemic hierarchies (Grosfoguel, 2009; Quijano, 2000). Eliding the role of the colonial encounter in bringing about western development, democracy and modernity more broadly, western epistemologies have imagined that knowledges arising from a particular western history comprise a 'universalistic, neutral, objective point of view' (Grosfoguel, 2009, 13; Mignolo, 2007). This conflation of 'the concrete hegemony derived from' western power and an 'abstract universality' that ought to be accepted and adopted everywhere gives western 'local knowledges and histories' the status of 'global designs', valid, applicable, and, when entangled with hierarchies of military and economic power, enforced everywhere (Dussel, 2000, 471; Mignolo, 2000, 17). This universalisation of local knowledge threatens 'the conversion of the knowledges of colonised people and of the diversity of their cultures and cosmologies to expressions of irrationality' (Santos, Nunes and Meneses, 2007, xxxiii). 'At best', perspectives from the other side of the colonial divide provide 'practical and local 
forms of knowledge', subordinate to the west's purportedly universal and globally applicable knowledge (Santos, Nunes and Meneses, 2007, xxxv).

Epistemic coloniality remains prevalent in literature on the localisation and vernacularisation of norms. 'Localisation' sees actors outside the 'west', albeit usually elite ones, engage in an 'active construction... of foreign ideas' (Acharya, 2004, 245). But localisation involves adapting norms at a local level; non-western actors produce only particular, local knowledges by adapting already-existing global designs. Relatedly, literature on vernacularization indicates that 'local geographies of history and culture' play a role in the 'appropriation and adoption of globally generated ideas and strategies' (Levitt and Merry, 2009, 441). Empirical work on vernacularisation is concerned with how human rights 'are vernacularised to fit particular historical and social contexts' as 'local values and culture' influence the way in which 'rights are actually appropriated' on the ground (Levitt and Merry, 2009, 442; Mujica and Meza, 2009, 505). A hierarchy thus remains between already-universal and otherwise unchanging global norms and a vernacular culture or language into which grassroots and southern actors translate them. Moreover, the dichotomy between global norms and local cultures is understood by Levitt and Merry $(2009,457)$ to give rise to an 'advocacy dilemma' - a trade-off between pursuing transformative change and securing local acceptance. 'When organisations use human rights in ways that join readily with existing issues and strategies, they are more readily accepted but represent less of a challenge to the status quo' (Levitt and Merry, 2009, 457). Put differently, if global norms are substantially re-shaped to fit local narratives, they do not challenge existing orders. But when vernacularisers 'rely on ideologies that are more ambitious and challenging', they 'have more difficulty establishing local support and enthusiasm' and depend instead on 'external sources of support, inspiration and funding' (Levitt and Merry, 2009, 457). Hierarchies between global and local norms are thus deepened as 'ambitious', 'challenging' and 'dramatic' forms of change are aligned with global norms whilst local cultures remain a site of conservatism (Levitt and Merry, 2009, 457). ${ }^{1}$ Peasant activism, by contrast, has seen grassroots and southern actors construct a transformative global norm.

Epistemic hierarchies also remain in attempts to identify the 'non-western' agency involved in the construction of norms. Despite demonstrating that non-western agents are "norm-

\footnotetext{
${ }^{1}$ See Sabaratnam $(2013,266-268)$ for a related criticism of literature on post-liberal peace building, which also equates western perspectives with the international/global and non-western perspectives with local cultures
} 
makers in world politics', Bettiza and Dionigi $(2014,1)$ preserve elitist tendencies by virtue of their methodological focus on the paper trail generated by the 'Organisation of Islamic Conference and its member states' effort to promote' norms within the UN. Moreover, by identifying a process of 'institutional translation' as a key causal mechanism in the diffusion of non-western norms Bettiza and Dionigi $(2014,1)$ reproduce west-centric tendencies that, as I shall later indicate, exist in the norm diffusion process itself. Institutional translation occurs when actors outside the west set candidate norms 'in harmony with the secularised and liberal language of UN resolutions' by stripping them of 'thick culturally embedded' content (Bettiza and Dionigi, 2014, 3). Non-western actors become norm makers only by complying with an already written global design, with a secularised and liberal script remaining the 'normative referent in world politics' (Hobson, 2012, 1). Food sovereignty, by contrast, has travelled as grassroots actors in the south and the north have suffused the norm with diverse, thickly embedded cultural perspectives.

Work on the localisation, vernacularisation and non-western authorship of norms does not suffice to decolonise and democratise norm diffusion. What, then, would it mean to decolonise and democratise norm diffusion? A survival of local and vernacular perspectives does not suffice on the basis that it risks reinforcing hierarchies in which grassroots and southern actors produce local norms whilst elite and western actors produce globally significant ones. Global decolonial solutions therefore involve 'the rearticulation and appropriation', not just the localisation and vernacularisation, 'of global designs from the perspective of' multiple knowledges, cultures and histories (Mignolo, 2000, 39). Such rearticulation requires a multifaceted and collective project, utilising a variety of strategies (see Sabaratnam, 2011, 785-793 and 2013, 270-274). In the context of norm diffusion, strategies include challenging representations of localities in the south as conservative and incapable of authoring transformative norms, deconstructing myths identifying the west as the exclusive and independent origin of modern global norms, restoring marginalised voices, practices and perspectives, and altering major inequalities in the power, resources and platforms that people have in shaping and spreading global norms. Collectively, these strategies challenge the multiple hierarchies shaping who can produce and spread global norms. Decolonising norm diffusion also involves democratising 'global' and 'universal' norms. The 'global', when it comprises a particular perspective universalising itself as a global design, risks reinforcing epistemic aspects of coloniality. The globality of norms should not be understood to arise from an already-existing universality which enables norms 
emerging in one locality to be accepted everywhere once they are stripped of particular cultural baggage. Instead, decolonial global norms would emerge, travel, and gain global significance through a democratic process of inter-cultural exchange across different yet resonant local perspectives and contexts. In so doing, they would become 'pluriversal' norms - norms that construct common global projects across diverse worldviews whilst respecting 'the multiples of local particularities' by enabling a world in which many worlds are possible (Grosfoguel, 2009, 33). This re-articulation of the globality of norms indicates that decolonising and democratising norm diffusion involve one another. If the global diffusion of a norm is to reflect a justice cascade, and not a colonial expansion in which one local perspective sets itself up as a universal, global value, the norm must travel through democratic dialogue 'between diverse critical epistemic/ethical/political projects' (Grosfoguel, 2009, 11; Santos, Nunes and Meneses, 2007).

Decolonising and democratising norm diffusion requires sustained collective struggle. My task here is the more limited one of attempting to decolonise and democratise norm diffusion scholarship. This step is important in moving norm diffusion scholarship away from its complicity with and towards a position from which it can be critical of west-centric and elitist tendencies in the norm diffusion process itself. A methodological shift enables me to identify the role southern and grassroots actors play in the construction and diffusion of norms. Typically, norm diffusion scholarship takes the universal nature of norms for granted. These norms are said to be constructed and promoted by elite norm entrepreneurs with an institutional platform. West-centrism and elitism are thus embedded in norm diffusion scholarship from the start. But they risk being magnified further as the work of elite norm diffusers is revealed primarily through an analysis of the 'trail of communication' generated within formal organisations of global governance and national government as they discuss and adopt norms (Finnemore and Sikkink, 1998, 892). ${ }^{2}$ This approach offers no way of judging whether the norm in question reflects particular understandings masquerading as universal values, and therefore cannot determine whether its diffusion involves colonial oppression or a justice cascade. Decolonial studies of the diffusion of norms might begin instead by exploring the construction of norms in and the travel of norms across diverse political mobilisations. This methodological shift requires looking beyond the paper trail of discussions in formal governance and government institutions and engaging with literature

\footnotetext{
${ }^{2}$ Levitt and Merry (2009) and Zwingel (2012) provide exceptions.
} 
produced by, and sociological and anthropological literature on, grassroots social and political movements. This methodological shift enables me to highlight the voices of grassroots and southern actors in the diffusion of food sovereignty, which in turn enables constructive and critical moves.

I make constructive moves in the following section. Exploring the emergence of food sovereignty in and the travel of food sovereignty across diverse grassroots mobilisations enables me to indicate three ways in which peasant activism counters west-centric and elitist tendencies in norm diffusion scholarship. First, contra localisation and vernacularisation, grassroots peasant activism has constructed and spread a pluriversal global norm. Second, the cultures and perspectives of these grassroots activists are not, contra Levitt and Merry, sources of conservatism, but are acting as a transformative influence on global norms. Finally, contra Bettiza and Dionigi, food sovereignty has not lost its thickly embedded cultural content in order to travel globally.

I make a critical move in the section on UN discussions concerning food sovereignty and peasants' rights. I suggest that institutional translation is starting to take place, resulting in a marginalisation of grassroots peasant voices. This marginalisation is not immediately obvious from the paper trail generated by institutional discussions, and can only be identified once the character of the norm produced by grassroots actors is understood. Starting with the construction and travel of norms across grassroots mobilisations will enable norm diffusion scholarship to identify what is lost as a norm travels through institutions, rendering it able to critique, rather than reproduce, elitist and west-centric tendencies in the norm diffusion process.

\section{Food sovereignty in grassroots mobilisations}

Food sovereignty emerged from a transnational network of grassroots peasant organisations, LVC, in response to transnational dynamics threatening autonomous peasant livelihoods. After introducing the problems faced by peasants and outlining LVC, I indicate how food sovereignty is thickly embedded in the histories, cultures and political contexts of grassroots peasant mobilisations. I then explore how transnational resonances and inter-cultural exchanges across diverse local perspectives have led to the development of a globally significant and pluriversal food sovereignty norm. Finally, I compare food sovereignty with 
existing global norms of food security and a right to adequate food in order to highlight its transformative potential.

Peasants, defined here as smallholder producers and gatherers that make a living from the land and sea, have long faced threats to their livelihoods. Developmentalist agendas saw peasants removed from land as part of a green revolution in agriculture. Agricultural modernisation between 1964 and 1985 in Brazil, for instance, had 'devastating social effects' including increasing land inequality and mass migration from rural areas into urban slums (Wolford, 2004, 411). In recent decades free trade regimes, combined with agricultural subsidies in food exporting countries in the north, have seen cheap industrially produced food sold in the global south at below the domestic cost of production, forcing domestic farmers who cannot compete with cheap imports to leave the land (Martínez-Torres and Rosset, 2010, 162). This resultant decline in peasant production leaves people and countries increasingly dependent on imported food, rendering them vulnerable to subsequent increases in food prices. Such increased prices were at the heart of the food crisis starting in late 2007. The food crisis combined with crises of energy, environment and finance to generate a new wave of land grabbing, as land was simultaneously demanded for agro-industrial food production, biofuel production, conservation purposes, and speculative investment (White et al, 2012). Though the scale of land grabbing and the methodologies and politics behind its measurement are contested (Scoones et al, 2013), what is clear is that there has been an increase in large scale land deals. These deals drive 'processes towards an even greater concentration of land' (Borras and Franco, 2013, 1738). Consequently, they shut down a world in which multiple and diverse autonomous smallholder alternatives are possible by clearing peasant producers from land, by enclosing land that might be distributed to smallholder producers, or by incorporating smallholders into corporate supply chains, often on adverse terms, as workers or contract farmers (White et al, 2012; Borras and Franco, 2013).

Resistance to threats to autonomous peasant livelihoods does not arise automatically, nor do struggles against land grabbing always demand the same thing - some are concerned with the land grab itself and others with the terms of compensation or incorporation (Borras and Franco, 2013). There is not, then, a homogeneous local community that automatically unites to contest globalised forms of oppression. Nor is grassroots activism inherently free from power and oppression. But grassroots peasant activists have nonetheless identified 
commonalities in a fight for a world in which their different worlds of living from the land and sea are possible. A new and pluriversal norm of food sovereignty, a peoples' right to 'produce our own food in our own territory', is central to this resistance (LVC, 1996). Food sovereignty was coined by LVC, a transnational network that now includes 164 peasant and indigenous organisations across five continents. LVC is structured in a democratic manner, enabling grassroots voices to come to the fore. The highest decision making body is an international conference, attended by delegates from each member organisation. Campaigns, strategies and general directions for the movement are shaped through participatory discussion, dialogue, consultation and working group discussions, with decisions made by consensus (VC, 2014b, 4). Each member organisation is expected to bring a delegation composed of $50 \%$ women and 33\% youth, and women's and youth assemblies precede meetings held between all delegates to ensure that gender and age-based hierarchies are challenged (VC, 2014b, 3). In bringing together a variety of groups from across the world, LVC conferences provide a 'space of encounter among different cultures and cosmovisions of the rural world' (Rosset, 2013, 724). LVC has therefore developed organisational structures that foster democratic inter-cultural exchange amongst grassroots peasant and indigenous actors in the north and the south. These structures help LVC live up to its claim to be 'a grassroots mass movement whose vitality and legitimacy comes from farmers' organisations at a local...level' (VC, 2011a).

\section{(a) The construction of food sovereignty}

The term food sovereignty had been used to mean something akin to national food security or food self-sufficiency in a Mexican government program in the early 1980s (Edelman, 2014a). But in 1996, at the second international LVC conference in Tlaxcala, Mexico, 69 peasant organisations from 37 countries across the Americas, Europe, Asia and Africa reappropriated the term. Inter-cultural dialogue amongst the diverse groups at this meeting enabled a new norm of food sovereignty - a right to produce our own food in our own territory - to emerge. Food sovereignty, then, was always a transnational project, involving grassroots agency in both the north and the south. But despite crystallising at the Tlaxcala conference, food sovereignty is rooted in the cultures and contexts of the grassroots peasant movements that form LVC. As an illustrative example, I mention the land occupation practices of the landless workers movement (MST) in Brazil, but peasant movements with resonant agendas exist in multiple places including Indonesia (Purwanto, 2013), Bolivia (Cockburn, 2013), and France (Heller, 2013). 
In an attempt to enable smallholder production, peasant movements in Brazil, of which the MST is the most famous, reach out to impoverished sections of Brazilian society, recruiting them to join land occupations at which they analyse the sources of their oppression and learn skills that enable them to (re)turn to farming. ${ }^{3}$ In MST occupations, the priorities and practices of the movement are shaped through democratic assemblies (Vergara-Camus, 2009, 185). In the context of these discussions amongst grassroots members, demands for existing national rights to land (Brazilian constitution, article 23) and international rights to food are transformed into calls for food sovereignty as they are embedded in peasant histories, cultures and contexts. Aforementioned histories of dispossession, which have led to deep scepticism amongst MST members of the ability of large-scale agriculture to provide food for all, have been understood through a peasant culture of attachment to land, particularly amongst occupiers in southern regions of Brazil. Settlers in Santa Catarina identified working on the land as 'a tradition in and of itself and a means for continuation of a life many found extremely valuable' (Wolford, 2004, 415), whilst one occupier (interviewed in Diniz and Gilbert, 2013, 210) indicated that they 'think of the land as a mother...she sustains every family and brings life'. Having land means, as one young MST settler put it (interviewed in Wolford, 2004, 415), having 'the dignity of being able to produce'; a statement which reflects a wide held belief that 'land is life' and that 'on the land, you don't go hungry' (MST activist, interviewed in Wolford, 2005, 204). Combined with histories of dispossession, cultural ties to land inspire grassroots activists to stitch together rights to food and land, with access to land deemed crucial to ensure an ongoing supply of food. This conjoined right to food and land is understood to be fundamentally collective by virtue of a political context in which only collective land occupations have forced the governments' hand in pursuing land reform. The government sometimes legalise occupations or give the occupiers an alternative plot of land. Though it has slowed under current President Dilma Rousseff, such MST-led land reform has consistently outweighed government-led land reform in terms of the number of people settled (Carter, 2014). Thus, as movement representative João Pedro Stédile (interviewed in Garmany and Maia, 2008, 188) highlights, 'the only way that we can secure public space is when we have a lot of people'.

\footnotetext{
${ }^{3}$ As documented by Loera (2010), a number of MST activists have been involved in a variety of peasant movements, moving between them in the hope of obtaining land.
} 
Resonant histories, cultures and contexts are shared amongst peasant movements across the world, meaning that 'anything that happened within the MST struck a chord within LVC' (VC, 2014a). Common cultural and historical attachments to land and shared transnational threats to peasant autonomy have thus enabled a 'vernacularisation in reverse' in which shared understandings emerge as ideas travel across different worldviews (Edelman, 2014b). These shared understandings were discovered and deepened through inter-cultural communication between peasants at the Tlaxcala conference, enabling movements with diverse yet resonant cultures and contexts to construct a common idea of food sovereignty, a fundamentally collective and conjoined right to food and land, or a right to produce our own food in our own territory. Food sovereignty, a candidate global norm, was thus authored by, and remains thickly embedded in the cultures of, grassroots activists in the south and the north.

\section{(b) How food sovereignty has travelled}

Grassroots peasant activism has been crucial in the diffusion of food sovereignty. LVC introduced food sovereignty to global discussions at a parallel civil society forum during the Rome world food summit in 1996. Initially, they did not get much support, with discourse dominated instead with norms of food security and the right to food. But LVC's persistent voice, expressed at global events like the world food summit, at counter-summit protests and through annual days of peasant struggle generated growing awareness of food sovereignty. This increasing recognition saw the food sovereignty movement grow in Africa, where LVC was previously less well represented. LVC and the Network of Peasant Organisations and Producers in West Africa (ROPPA) issued a joint call for food sovereignty in 2001 (ROPPA and VC, 2001). Since, calls for food sovereignty have proliferated in West Africa and across the African continent. LVC's African region was founded in 2004 and in 2011, an Alliance for Food Sovereignty in Africa was formed from a range of peasant, environmental, indigenous and other movements.

Communication amongst LVC and the other movements committed to transforming agriculture that were involved in the civil society forum of the 1996 Rome summit also led to the formation of an International Planning Committee for Food Sovereignty (IPC) in 2000. The IPC is composed of over 800 organisations, representing over 300 million small-scale food producers (IPC, 2015, about us). Like LVC, decisions about positions and movement directions are made by organisations of small food producers, with NGOs playing only a 
supporting role (IPC, 2015). The IPC's initial role, as I shall discuss later, was in discussions within the UN Food and Agriculture Organisation (FAO), where they helped bring food sovereignty to the ears of UN actors. But they have also fostered inter-cultural dialogue across multiple rural movements. Such exchanges have ensured that food sovereignty has travelled through the development of commonalities amongst diverse grassroots actors, and not as an abstract universal which sees particular histories represented as global designs. Along with LVC and others, the IPC organised the 2006 'Land, Territory and Dignity' forum in Porto Alegre and the 2007 'Nyeleni' forum in Mali. These conferences included the different perspectives provided by fisherfolk, pastoralists, and indigenous peoples. Discussions amongst landless workers, smallholder farmers, fisherfolk, pastoralists and indigenous peoples helped broaden the food sovereignty norm and the food sovereignty movement through a renewed emphasis on the concept of shared territory. A right to produce our own food in our own territory has always been part of food sovereignty, reflecting both the involvement of indigenous peoples in early LVC meetings and the concerns of some peasant groups with restoring ancestral territories. But food sovereignty was initially constructed primarily by peasant movements which, like the MST, demanded state-led land reform as a means of acquiring family-owned plots of land. Indigenous peoples, pastoralists and fisherfolk tend to be concerned instead with the wider territory across which they move, from which they live, and in which they have ancestral memories (Rosset, 2013, 722). Moreover, some indigenous cosmovisions emphasise that living well, or buen vivir, is only possible collectively, through an 'interrelation of beings, knowledges, logics and rationalities of thought, action, existence and living' across a shared territory (Walsh, 2010, 18). The broadened vision of food sovereignty that emerged through these inter-cultural exchanges is reflected in the Porto Alegre forum's statement indicating that agrarian reform 'must include the cosmovisions of territory of communities of peasants, the landless, indigenous peoples, rural workers, fisherfolk, nomadic pastoralists' and others who 'maintain a relationship of respect and harmony with the mother earth' (Land, Territory and Dignity, 2006).

Inter-cultural dialogue across diverse peasant, indigenous, pastoralist and fisherfolk worldviews developed commonalities across divergent and potentially conflicting worldviews via recognition that enabling autonomous smallholder production must not involve an enclosure or pollution of land or water used by indigenous peoples, pastoralists and fisherfolk. These commonalities were only possible via a deepening of the collective nature of food sovereignty and via a strong commitment to ecologically friendly forms of 
production. Unless a wider territory is shared and protected from degradation and despoilment, smallholder farmers producing their own food in their own territory could undermine alternative ways of living autonomously from the land and sea. These intercultural exchanges continued both at the 2007 Nyeleni forum, which led to a declaration on food sovereignty authored by over 500 representatives from more than 80 countries (VC, 2007), and at a range of further gatherings (Rosset, 2013; Martínez-Torres and Rosset, 2014). Such exchanges show that food sovereignty has not travelled by being stripped of thickly embedded cultural content to reveal an abstract universality. Instead, food sovereignty has become globally significant through inter-cultural exchanges through which diverse perspectives enrich food sovereignty as they suffuse it with their particular worldviews. Such exchanges have enabled food sovereignty to develop into a pluriversal norm that fights for a world in which shared use and collective stewardship of territories makes the co-existence of diverse peasant, indigenous, pastoralist and fisherfolk worlds possible.

European participants inspired by the Nyeleni forum subsequently organised Nyeleni Europe, an international network aiming to realise food sovereignty in Europe, and a Nyeleni Europe forum, held in 2011. This is reflective of the broader way in which food sovereignty, which has always been a transnational project across north and south, has continued to inspire further mobilisations in the global north. Diverse mobilisations in the north each articulate their own version of food sovereignty, reflecting once more its pluriversality. Food sovereignty has been demanded through direct actions ranging from land occupations in rural Andalusia and the occupation and use of fertile urban land in Vienna for community supported agriculture (Transnational Institute, 2013). In these cases, food sovereignty has been given a do-it-yourself ethos as it is worked through with the cultures and contexts of anarchist inspired movements (see also Reclaim the Fields, 2015). By contrast, community groups in the USA have interpreted food sovereignty through a culture of localism, attempting to protect smallholder producers through local food sovereignty laws (Bellinger and Fakhri, 2013). Other movements like the Landworkers Alliance in the UK have pursued food sovereignty through lobbying activity demanding national policy measures that support ecologically friendly smallholder production (Landworkers Alliance, 2014).

Instigating a methodological shift and beginning an analysis of food sovereignty by exploring its emergence within and travel across grassroots mobilisations has started to mitigate elitist and west-centric tendencies in norm diffusion scholarship. That food sovereignty has spread 
from grassroots peasant activism, including activism in the south, to inspire diverse mobilisations in the north indicates that, contra notions of localisation and vernacularisation, grassroots and southern actors can author globally significant norms. Moreover, as food sovereignty has travelled, it has remained a demand for collective and democratic control of a food system based on smallholder production, and therefore has not, at this stage at least, been stripped of the content inspired by peasant cultures and histories in order to be expressed in the 'liberal language' of individual rights (Bettiza and Dionigi, 2014, 12). Rather, food sovereignty has been suffused with diverse perspectives as it enters different locales, sometimes engendering do-it-yourself forms of direct action, sometimes localised legal demands, and sometimes lobbying activity. The spread of food sovereignty, then, displaces a west-rest dichotomy, where norms from the non-west must be stripped of their 'thick culturally embedded' content if they are to travel to the west (Bettiza and Dionigi, 2014, 3). Finally, food sovereignty constitutes a decolonial global norm insofar as it has emerged and travelled through inter-cultural exchange across diverse perspectives. In the face of a food system that shuts down alternative worlds by enclosing land, inter-cultural exchanges have given rise to a common demand for a world in which the diverse agricultural systems through which peoples produce their own food in their own territory are possible. Food sovereignty therefore does not represent a particular worldview adopting the cover of a universal, global design, and is instead a pluriversal norm demanding a world in which many words are possible. What I am yet to show is how grassroots cultures can, contra Levitt and Merry (2009, 457), operate as a transformative and not a conservative force. Highlighting the distinctiveness of food sovereignty vis-à-vis existing norms of food security and the right to adequate food shall demonstrate the radical and transformative potential of food sovereignty.

\section{(c) Food sovereignty: a transformative norm}

Food security, the right to adequate food and food sovereignty are contested and overlapping concepts, making it difficult to draw clear lines between them. But a distinction can be made between the central emphases of each concept. Food security, on the FAO's (2015, 53, my emphasis) interpretation, 'exists when all people...have physical, social and economic access to sufficient, safe and nutritious food'. This formulation says nothing about the way in which food is produced, and is compatible with the distribution of food produced by agribusiness to individuals who cannot provide food for themselves. The right to adequate food also demands sufficient nutritious food, but 'goes beyond' food security by understanding access to food as a right that generates legal obligations (Ziegler et al, 2011, 5). Right to food advocacy has 
ensured that this legal obligation is enshrined not only in the International Convention of Economic, Social and Cultural Rights but also in a range of further international guidelines and national constitutions and laws. In part through the influence of exchanges with the food sovereignty movement, key advocates of the right to food have, as discussed later, recognised that agrarian reform and ecologically friendly smallholder production - key aspects of food sovereignty - are the best means toward providing safe, sufficient and nutritious food (Ziegler et al, 2011, 34-41). But they remain a means towards a legal right, held by individuals, to be free from hunger (Windfuhr and Jonsén, 2005). If a food system based on the large-scale industrial production and free global trade of food could ensure that all individuals have access to adequate food, this globalised industrial food system would not, in principle at least, violate an individual's right to food.

The central emphasis of food sovereignty is on a broader collective and political programme aimed at transforming the way in which food is produced. Food sovereignty puts small-scale producers 'at the heart of food systems'; a shift which endows food sovereignty with at least four distinctive features (VC, 2007, 673). First, food sovereignty makes environmentally friendly and autonomous smallholder production central, demanding not only access to or a right to food but also rights to territory and agricultural inputs including seeds. Second, reference to producing our own food has developed into a broader right of peoples to 'define their own food and agriculture systems', indicating that democratic decision making over agricultural issues is central to food sovereignty (VC, 2007, 673). Third, in response to the dispossession and adverse incorporation that have resulted from a globalised industrial food system, food sovereignty involves giving smallholders rights to reject agro-industrial methods of and inputs for production, including genetically modified seeds. Finally, where the right to food focuses on protecting individuals, food sovereignty is a fundamentally collective right providing shared access to and shared use of resources within a territory (VC, 2007).

The radical potential of food sovereignty indicates that grassroots cultures in the south and north have not acted as an obstacle to radical and transformative ideas. The globalised industrial food system to which it objects has served to replace diverse smallholder production with large-scale monoculture production. Large plots are farmed using highenergy, mechanised forms of agriculture. These 'field-level practices represent approximately 15 percent of total human-made greenhouse gas emissions. ${ }^{i}$ Moreover, such a system 
requires inputs, including fertilisers, and operates by transporting food across the world, making industrial forms of agriculture responsible for adding a further 15-17 per cent of total man-made greenhouse gas emissions. ${ }^{\text {ii }}$ These methods also degrade land, leading to decreasing food yields, meaning that 'under a business-as-usual scenario, we can anticipate an average of 2 per cent productivity decline over each of the coming decades'. iii This globalised industrial system of food production currently sees 795 million people remain chronically under-nourished, even as plentiful food is produced (FAO, 2015, 4). Food sovereignty demands wholesale changes to this productive system. Smallholder production that does not require energy-intensive technological inputs would replace agro-industrial methods, and more food would be produced and consumed at a local level. Rather than blocking radical change, food sovereignty aims to return peasants to land, ease climatic crises, and undercut dependence on ongoing access to external inputs and cheap energy. Whilst LVC's claim that this food sovereignty alternative can feed the world whilst cooling the planet remains contested, what is clear is that peasant actors are now looking to instigate, rather than resist, global transformations (LVC, 2009). Far from representing 'less of a challenge to the status quo', diverse grassroots cultures across a range of locales have constructed a pluriversal global norm with radical and transformative potential (Levitt and Merry, 2009, 458).

\section{Food sovereignty and peasants' rights at the UN}

A methodological shift can mitigate elitist and west-centric tendencies in norm diffusion scholarship. But elitist and west-centric tendencies may nonetheless persist in practices through which norms travel. Food sovereignty has entered formal institutions of government by being incorporated into a number of laws and constitutions in Latin American, Caribbean, and West African states, and entered formal institutions of global governance by entering UN discussions concerning food, agriculture and peasants' rights. The extent to which food sovereignty laws reflect the concerns of grassroots activists varies from case to case (see Claeys, 2015, 29-41). My focus here is on the potential marginalisation of grassroots voices in discussions of food sovereignty within the UN. To this end, this section adopts the more conventional methodology of norm diffusion scholarship by exploring the paper trail generated by UN discussions concerning food sovereignty. Having previously identified elements that are central to the norm as constructed by grassroots actors, I am in a position to see whether the concerns of grassroots peasant actors - enabling environmentally friendly 
smallholder production, rights to reject agro-industrial production, and fundamentally collective and democratic control over the food system - continue to be acknowledged in UN discussions. As I shall demonstrate, the concerns of grassroots peasant actors risk being marginalised as a proposed declaration on the rights of peasants moves through the UN. This indicates that elitist and west-centric tendencies exist within the practices of developing a UN declaration.

\section{(a) UN Discussions}

Food sovereignty was first mentioned in UN discussions by LVC at the 1996 FAO world food summit. Food security and a right to food initially dominated discussions, but the growing food sovereignty movement, discussed previously, ensured that food sovereignty grew in prominence. The IPC organised a forum for food sovereignty at the follow up, 2002 world food summit. One year later, the FAO committed to working with the IPC as a focal point for civil society (IPC, 2015, timeline). This lobbying work has helped spread food sovereignty to the ears of actors with an institutional platform in discussions concerning the global governance of food and agriculture including then special rapporteur on the right to food Jean Ziegler. Ziegler's 2004 annual report, presented to the UN Commission on Human Rights (which later became the Human Rights Council - UNHRC), devoted an entire chapter to food sovereignty, suggesting that food sovereignty offered 'an alternative means...[to] better ensure the right to food'. ${ }^{\text {iv }}$ Ziegler's suggestion that food sovereignty 'be considered as an alternative model for agriculture and agricultural trade ${ }^{\mathrm{v}}$ was developed further in his 2008 report, which identified food sovereignty as a source of 'hope' and as a 'valuable solution' to 'better ensure the right to food'. vi

Ziegler's successor Olivier de Schutter shared LVC's analysis in identifying the agroindustrial, market-dominated way in which food is produced and distributed as the source of problems of hunger, environmental decline, and the dispossession or adverse incorporation of peasants. He continued to aid the food sovereignty movement by advocating land reform, ${ }^{\mathrm{vii}}$ calling for the extended involvement of peasant social movements in the global governance of food and agriculture, ${ }^{\text {vii }}$ and promoting environmentally friendly smallholder production as something that can 'feed the world, fight rural poverty, and combat climate change at the same time' (De Schutter, 2015). ${ }^{\text {ix }}$ These claims were echoed by his successor, Hilal Elver, who said that 'small farmers feed the world' when discussing the UN's decision to declare 2014 the international year of family farming (Elver, 2014). De Schutter's promotion of food 
sovereignty culminated in his final, 2014 report to the UNHRC, where he argued that 'food sovereignty is a condition for the full realisation of the right to food'. ${ }^{\mathrm{x}}$ Support from the special rapporteur on the right to food is reflective of a broader trend, which has seen prominent proponents of the right to food take seriously food sovereignty as a means to achieve or even precondition for securing the right to food. FoodFirst Information Network (FIAN), the largest NGO promoting and monitoring the right to food, for instance, have suggested that the 'interpretation' of the right to adequate food 'must be...updated and reconceptualised within the framework of food sovereignty' (Valente, 2014, 2).

\section{(b) The UN Declaration of Peasant Rights: a Loss of Peasant Voices?}

LVC has used support from actors with an institutional platform in the governance of food to attempt to generate new international principles to promote food sovereignty. To this end, promotion of food sovereignty has been incorporated into a broader declaration on the rights of peasants and other people working in rural areas, which is currently being discussed within the UNHRC.

A declaration on the rights of peasants was initially formulated through 'a bottom up mechanism, by peasants themselves' in Indonesia in 1999 (Purwanto, 2013, 8). It was 'quickly adopted by a broader, transnational coalition', first at a regional LVC conference in 2002, and then at the fourth international conference in 2004, where LVC decided to draft an international peasants' rights charter (Edelman and James, 2011, 92). A draft declaration written by delegates from 26 countries was deliberated upon and adopted at the fifth international LVC conference in 2008. At this conference, LVC devised strategies to take this draft 'declaration of rights of peasants - women and men', of which the food sovereignty norm is a central and guiding element, to the UN in order to develop new instruments of international law (VC, 2011b). A document based very closely on LVC's draft declaration has since been discussed at an inter-governmental working group on the adoption of a new resolution on the promotion and protection of the human rights of peasants and other people working in rural areas. ${ }^{x i}$ Thanks, then, to 'more than ten years work by human rights defenders and peasant organisations, in particular LVC', peasants' rights are emerging in international human rights law (Golay, 2015, 9). ${ }^{4}$ LVC's democratic and deliberative

\footnotetext{
${ }^{4}$ De Schutter has highlighted the work of grassroots actors in constructing this emerging law, noting that peasant activists are 'transforming our understanding of human rights' (in Claeys, 2015, acknowledgements).
} 
processes in drafting and adopting the document placed grassroots peasant voices at the heart of this emerging law.

The progress of peasants' rights through the UN system, though, has become increasingly dependent on elite actors, who have encouraged an institutional translation of rights to food sovereignty at the potential cost of marginalising grassroots voices. After drafting a declaration, LVC used the support they had won amongst actors with an institutional platform including FIAN and Ziegler 'as a door to peasants' rights' (LVC secretary general, interviewed in Claeys, 2015, 125). FIAN provided access to the human rights mechanisms of the UN by virtue of their consultative status with the Economic and Social Council, while Ziegler, who sat on the Human Rights Council Advisory Committee, provided knowledge of decision making bodies and procedures (Claeys, 2015, 56-62). Ziegler encouraged the UNHRC and general assembly to invite LVC 'to give its views on the ways in which the food crisis could be remedied' in 2009 (Golay, 2013, 6). LVC's response, that peasants' rights provided a means of responding to the food crisis, was taken forward by the UNHRC advisory committee in February 2009, who stated that 'the best way to further advance the protection of the rights of peasants and other people working in rural areas is to adopt a new instrument - initially, a declaration - to better promote and protect these rights'. ${ }^{\text {ii }}$ Subsequently, in September 2012, the inter-governmental working group was established by a vote of 23 to nine with 15 abstentions. ${ }^{\text {xii }}$

The working group, composed of 63 nation states and of civil society groups including FIAN and LVC, met in July 2013, with the 'mandate of negotiating, finalising and submitting to the UNHRC a draft UN declaration on the rights of peasants and other people working in rural areas'. ${ }^{\text {xiv }}$ After hearing panel discussions from a series of peasants' rights advocates, including Ziegler, de Schutter, and Saragih, they engaged in a reading of the draft declaration on the rights of peasants, put together by the Human Rights Council Advisory Committee using LVC's declaration 'as a model'. ${ }^{\mathrm{xv}}$ The advisory committee's draft declaration was almost identical to LVC's initial declaration, and contained the four aforementioned features of food sovereignty. Article 2:5 of the proposed declaration gives peasants 'the right to food sovereignty', indicating that this comprises of their collective and democratic 'right to determine their own food and agriculture systems', article 5 provides a 'right to reject the industrial model of agriculture', whilst Article 4.1 gives peasants 'the right to own land', providing means for enabling smallholder production. ${ }^{\mathrm{xvi}}$ 
This draft, though, met the resistance of elite actors. EU member states used their general statement to express 'concerns about the procedure that led to the Advisory Committee working without a mandate on a declaration that the Council had not requested' xvii That the demand and impetus for a declaration came from grassroots actors outside the UNHRC, then, appeared to be problematic procedurally. Moreover, a number of states were concerned that the document 'did not consistently adopt agreed UN language, notably when it asserted a right to reject' (Golay, 2015, 3). Although peasant actors, NGOs, and other states participated in this working group meeting, the UNHRC is structured such that only the 47 member states that sit on the council are able to vote. ${ }^{5 x v i i i}$ It is initially these member states and then, if the declaration is put forward to the general assembly, all UN member states, who decide whether or not a declaration will be adopted. Whilst a decision to continue the working group or adopt the declaration only requires a simple majority ${ }^{\mathrm{xix}}$, the UNHRC explores all avenues in pursuit of consensus on proposed declarations, in part because the legitimacy of any declaration depends on widespread agreement, and in part because a lack of consensus may lead to later proposals for amendments when a proposed declaration reaches the UN General Assembly (Charters and Stavenhagen, 2009). Unless changes were made to appease objecting states, the declaration of peasants' rights risked undergoing similar delays to a prior declaration on indigenous peoples' rights, where a combination of state objections and a principled refusal on behalf of indigenous peoples to change their draft declaration meant that it was over 20 years before a revised declaration was eventually adopted (Charters and Stavenhagen, 2009). To avoid such a situation, the working group chairperson-rapporteur and ambassador of Bolivia, Angélica C. Navarro Llanos, recommended that a second session be held to discuss a new text that she would write in consultation with governments, regional groups, intergovernmental organisations, civil society, and peasant representatives ${ }^{\mathrm{xx}} \mathrm{A}$ declaration based on inter-cultural dialogue and democratic exchange amongst diverse grassroots advocates of food sovereignty and peasants' rights was to give way to a declaration produced in a smaller set of meetings amongst predominantly elite actors with an institutional platform.

Before exploring the revised draft declaration, it is worth emphasising what LVC hope to achieve through a UN declaration. LVC is aware that a declaration will not be legally binding

\footnotetext{
${ }^{5}$ The 47 states are drawn proportionally from regional groups and elected by the UN general assembly.
} 
and will not automatically generate compliance. LVC has therefore remained 'realistic about the amount of energy that should be put into the $\mathrm{UN}$, maintaining its greatest strength on the ground mobilising farmers and building alternatives' (VC, 2013). A declaration remains a 'strategic vision' to support these wider 'social mobilisation[s]' (Nicholson, interviewed in Wittman, 2009, 679). Much as grassroots peasant movements, including the MST, have used existing rights to land and food as tool in their land occupations, LVC see a declaration of peasants' rights as something that can inspire, legitimate, and give bargaining power to future struggles. These struggles, moreover, are around a perceived clash of fundamentally incompatible models: one of large scale, globalised industrial production that degrades land, undercuts smallholder producers, results in food and climate crises, and undermines autonomous lifestyles, and one in which the diverse, environmentally friendly and autonomous ways of living from territories pursued by smallholders, pastoralists, indigenous peoples and fisherfolk work to cool the earth and feed the planet (Martínez-Torres and Rosset, 2010, 168). To ensure that the declaration can give legitimacy and strength to these struggles, it is vital that the distinctive features of food sovereignty, namely, democratic and collective control of the food system, enabling ecologically friendly smallholder production, and a right to reject agro-industrial food systems, are retained. The challenge for peasant organisations is to withstand pressures to reduce these novel demands to commonly used language, and to 'maintain this alternative conception as intact as possible, while...accepting changes in the draft text that make it acceptable to states' (Claeys, 2015, 61). Some movement members have expressed fears that, in negotiating this challenge, 'the spirit of the document will be lost' (Indonesian LVC activists, interviewed in Claeys, 2015, 105). The changes that have since been made suggest that this fear might be realised.

The UNHRC adopted a resolution to hold a second working group on 27 June 2014 by a vote of 29 to five, with 13 abstentions; a rise of six in the number of votes in favour, and a decline of four votes against. ${ }^{x x i}$ France, Austria, Germany, Italy and Ireland moved from opposition to abstention, in part thanks to the advocacy work performed by the European coordination of LVC. Despite this partial victory, further objections to the initial draft declaration were raised. Paolo Cuculi, the Italian delegate, suggested that the draft declaration was 'an inadequate basis' for ongoing discussion on the basis that it did not focus on the 'application of the existing human rights framework' to the situation of peasants, whilst Tabitha Snowbarger, the US delegate, indicated that the US were voting against ongoing talks on the basis that they focused on 'controversial new rights' and that they had not seen enough 'indication of 
readiness to move' toward focussing on already-existing rights. ${ }^{\text {xii }}$ Strategies for amending the declaration to meet these objections and generate further agreement were discussed during informal consultations between the chairperson-rapporteur, states, NGOs and representatives of peasants and other people working in rural areas. In addition, human rights expert Christophe Golay provided a background paper, advising on the changes that might ensure such agreement. In light of the objections to new rights and some states' preference to apply existing rights to the particular circumstances of peasants, Golay $(2015,66)$ indicated that a 'compromise' might be found by 'using agreed language and replacing the right to reject by a right to choose and to be protected'. To 'bridge differences' rights to reject should therefore be removed, rights should be framed in terms of language that states 'have already agreed in other instruments' (Golay, 2015, 76), and, with the exception of the irreducibly new right to food sovereignty, the declaration should seek to 'affirm existing human rights... and assert their application to the particular needs and vulnerabilities of peasants' (Golay, 2015, 75).

The chairperson-rapporteur's advanced draft declaration, which was discussed in the second intergovernmental working group and is due to be discussed further at a third meeting in 2016, shows that the strategies suggested by Golay have been pursued (UN, 2015). Some core elements of food sovereignty have survived, with article 5.4 granting peasants 'the right to food sovereignty' and defining food sovereignty as the democratic and collective 'right of peoples' 'to define their own food and agricultural system' (UN, 2015, my emphasis). But whilst food sovereignty has remained collective, the related rights through which it is secured have been interpreted as individual rights that can be exercised collectively. Moreover, rights to reject have been removed entirely, and replaced by rights to choose. Rights to reject seed varieties have become a 'right to decide which crops to cultivate' (UN, 2015, article 22:2) and rights to reject agro-industrial food production as a whole have become a 'right to decide whether or not to grant access to...natural resources' (UN, 2015, article 5.1). More damagingly, the document permits the 'exploitation of the natural resources of peasants' if a series of conditions regarding 'social and environmental impact assessment', 'consent', and 'modalities for sharing benefits' have been established (UN, 2015, article 5.6). This is indicative of a broader shift in which the declaration no longer rejects the agro-industrial food system in favour of a diversity of ways of living from territories that can feed the world and cool the planet. Instead, the declaration provides rights to pursue a smallholder alternative alongside ongoing agro-industrial production; rights that might appear paradoxical to those 
who see the continuation of the globalised industrial food system as inextricably linked to the closure of smallholder alternatives. Pressure from EU states and the USA, along with the advice of experts, have instigated a partial institutional translation of peasants' rights, substituting a liberal language of individual rights to choose for some of the fundamentally collective rights that were developed by grassroots actors, including actors in the south. The pluriversal norm of food sovereignty which lies at the heart of peasants' rights was developed collectively through inter-cultural dialogue across diverse local perspectives. But compliance with a set of already-existing, primarily individualistic global designs has become a condition for furthering the discussions through which peasant activists can enshrine norms that they have constructed in a UN declaration. The elitist and west-centric tendencies that I identified in norm diffusion scholarship are therefore at work within processes through which food sovereignty and peasants' rights might enter into international soft law.

Given the pressures to translate norms, peasant representatives have remained positive about the UN process, with Saragih welcoming the new text on the basis that it includes the key rights', in particular the fundamentally collective right to food sovereignty (VC, 2015). But if the institutional translation goes further and starts to question this fundamentally collective right to food sovereignty, it may be that the voices of grassroots actors in the south and north are lost entirely. There is a risk that the distinctive features that were embedded in peasant, indigenous, fisherfolk and pastoralist cultures and perspectives could get lost as fundamentally collective rights give way to individual rights that can be exercised collectively. Moreover, there is a danger that the changes could undermine the strategic benefits of the declaration. Recall that LVC regard these rights as a strategic device to legitimise and strengthen ongoing mobilisation around a clash of incompatible agricultural models. In removing a right to reject the globalised industrial food system as a whole, changes made so far may already compromise the declarations' ability to legitimise such a struggle. In addition, ongoing mobilisation requires the cohesion of a unified peasant movement. If the remaining collective right to food sovereignty is later translated into individual rights, peasants will be given individual rights to choose whether to grant access to natural resources (UN, 2015, article 5:1), whether or not to use certain seeds, and, subject to appropriate assessments, whether or not to allow agribusiness to exploit natural resources (UN, 2015, article 5:6). This may result in a situation where some peasants use these rights in order to choose to work with agri-business, to adopt particular seed varieties, and to allow the exploitation of resources on their particular patch of land (as they sometimes have in the past, 
see Fernandes et al, 2011, 801). Not only could this serve to divide the peasant movement and deprive them of their collective strength, but it might also make other worlds impossible by undermining those who do not make these choices. Nearby agro-industrial production might degrade land in the surrounding territory, whilst seed varieties might travel to nearby peasant farms resulting in cross-fertilisation. Thus, if institutional translation goes further, the resultant declaration might write out the voices of grassroots actors in a manner that reduces the transformative potential of food sovereignty, undermines the usefulness of the declaration for ongoing mobilisation and even enables forms of agriculture and resource exploitation that risk making other smallholder alternatives impossible.

\section{Conclusion}

By exploring the emergence of food sovereignty in and the travel of food sovereignty across grassroots mobilisations, I have highlighted the role that grassroots and southern actors have played in the construction and diffusion of food sovereignty. In so doing, I have attempted to mitigate tendencies of west-centrism and elitism in norm diffusion scholarship. Contra Levitt and Merry's advocacy dilemma, which depicted local, grassroots actors as conservative vernacularisers of already global norms, food sovereignty saw grassroots activists author a transformative global norm. Contra Bettiza and Dionigi, food sovereignty did not diffuse across grassroots mobilisations by virtue of a process of institutional translation which rendered it acceptable to a 'liberal' yet purportedly global society. Instead, through intercultural exchanges, a diversity of grassroots actors enriched food sovereignty with their diverse cultures and perspectives in order to generate a pluriversal norm of food sovereignty.

Tracking the diffusion of food sovereignty through recent UN discussions concerning a declaration on the rights of peasants, though, revealed that a process of institutional translation is starting to take place, with grassroots peasant voices being marginalised in favour of the liberal and individualistic language common to existing declarations. Westcentric and elitist tendencies in norm diffusion literature thus reflect the difficulty southern and grassroots activists have in being recognised as they enter into UN discussions. Acknowledging the way in which southern and grassroots voices are being lost has implications for norm diffusion scholarship, for the food sovereignty movement, and for

global society more broadly. For norm diffusion scholarship, it suggests that a methodological shift is required in order to take seriously the agency of grassroots actors, 
including grassroots actors in the south. Instead of taking the universality of a norm for granted before analysing the trail of communication generated in high-level institutional discussions regarding norms, analysis should begin with the construction of norms in and the travel of norms across grassroots mobilisations. This shift enables norm diffusion scholarship to identify grassroots and southern agency in the construction of norms, assess whether the diffusion of a norm involves a colonial projection of particular worldviews or an establishment of commonalities amongst diverse worldviews, and analyse whether subsequent high-level discussions marginalise southern and grassroots voices. Through this shift, norm diffusion scholarship can move away from its current complicity with and toward a critique of practices that marginalise grassroots and southern voices. For the food sovereignty movement, it suggests caution in ceding further ground in translating food sovereignty and peasants' rights. So doing might undermine the usefulness of the declaration in supporting ongoing mobilisation. It is therefore important to hold out for the fundamentally collective right of food sovereignty, to the point that it might be worth debating whether to leave the process if this key part of the idea that grassroots activists have worked so hard to construct and diffuse is removed. Finally, if the norm diffusion process itself is to be decolonised and democratised, then global society might learn from the forms of intercultural exchange that marked the construction and initial spread of food sovereignty. To this end, extending UN discussions on the declaration of peasants' rights from the exclusive purview of states, experts, elites with institutional platforms and a handful of peasant representatives, and maintaining an open attitude to new and transformative ideas, will be crucial if the novel demands made by grassroots actors are not to be reduced to a reaffirmation of existing rights. Taking seriously these implications might offer hope not only for decolonising and democratising norm diffusion scholarship, but also for starting to decolonise and democratise the norm diffusion process itself.

\section{Bibliography:}

Acharya A (2004) How ideas spread: whose norms matter? Norm localization and institutional change in Asian regionalism. International Organization 58(2): 239-275.

Bellinger N and Fakhri M (2013) The intersection between food sovereignty and law. Natural Resources \& Environment 28(2): 1-4

Bettiza G and Dionigi F (2014) How do religious norms diffuse? Institutional translation and international change in a post-secular world society. European Journal of International Relations. Epub ahead of print 8 August 2014. DOI: 10.1177/1354066114542663.

Borras SM Jr. and Franco JC (2013) Global land grabbing and political reactions 'from below'. Third World Quarterly 34(9): 1723-1747 
http://www.stf.jus.br/repositorio/cms/portalStfInternacional/portalStfSobreCorte en us/anex o/constituicao ingles 3ed2010.pdf (accessed 15 April 2015).

Carter M (2014) Authoritarian Legacies, Democracy and Popular Resistance in the Brazilian Countryside, Presentation. Available at: http://www.norlarnet.uio.no/pdf/events/2014/fromcoup/carter.pdf (accessed 04 February 2015).

Charters C and Stavenhagen R (eds) (2009) Making the Declaration Work: The United Nations Declaration on the Rights of Indigenous Persons. Copenhagen: International Work Group for Indigenous Affairs

Claeys P (2015) Human Rights and the Food Sovereignty Movement. London: Routledge.

Cockburn J. (2013) Bolivia's food sovereignty and agrobiodiversity, in Food Sovereignty: A Critical Dialogue, Yale University, USA, 14-15 September 2013. Available at: http://www.yale.edu/agrarianstudies/foodsovereignty/pprs/59_Cockburn_2013.pdf, (accessed 27 May 2015).

De Schutter O Agroecology'. Available at: http://www.srfood.org/en/agroecology?hc location=ufi (accessed 27 May 2015).

Diniz AS and Gilbert B (2013) Socialist values and cooperation in Brazil's landless rural workers movement. Latin American Perspectives 40(4): 19-34.

Dussel E (2000) Europe, Modernity and Eurocentrism, Neplanta: Views from South 1(3): 465-478)

Edelman M (2014a) Food sovereignty: forgotten genealogies and future regulatory challenges. Journal of Peasant Studies 41(6): 959-978.

Edelman M (2014b) Dispatch from Geneva: A treaty on transnational corporations? A declaration on peasants' rights? FocaalBlog, July 17, available at http://www.focaalblog.com/2014/07/17/dispatch-from-geneva-a-treaty-on-transnationalcorporations-a-declaration-on-peasants-rights (accessed 31 July 2015)

Edelman M and James C (2011) Peasants' rights and the UN system. Journal of Peasant Studies 38(1): 81-108.

Elver H. Speech to Transnational Institute, 19 September 2014, available at http://www.tni.org/article/un-only-small-farmers-and-agroecology-can-feed-world (accessed 27 May 2015).

Escobar A (2012) Encountering Development, Oxford: Princeton University Press

European Coordination Vía Campesina (2014) Hands off the Land. Amsterdan: Transnational Institute.

Fernandes BM, Welch CA and Gonçalves EC (2010) Agrofuel policies in Brazil. Journal of Peasant Studies 37(4): 793-819.

Food and Agriculture Organization (FAO) (2015) The state of food insecurity in the world 2015. Rome: United Nations.

Garmany J and Maia F (2008) Considering Space, Politics, and Social Movements: an Interview with João Pedro Stédile. Antipode 40(2): 187-191.

Golay C. (2013) Legal reflections on the rights of peasants and other people working in rural areas, Geneva: Geneva Academy

Golay, C. (2015) Negotiation of a UN declaration on the rights of peasants and other people working in rural areas, Background paper, Geneva: Geneva Academy.

Grosfoguel R (2009) A decolonial approach to political-economy, Kult 6, Special Issue: 1038

Hobson JM (2012) The Eurocentric Conception of World Politics: Western International Theory, 1760-2010. New York: Cambridge University Press 
International Planning Committee for Food Sovereignty (IPC) About us. Available at: http://www.foodsovereignty.org/about-us/ (accessed 27 May 2015)

Land, Territory and Dignity Forum (2006) For a new agrarian reform based on food sovereignty! Available at http://www.cndwebzine.hcp.ma/cnd sii/IMG/pdf/ZZZZZZZZZ6.pdf (accessed 27 July 2015)

Landworkers Alliance (2014), Feeding the future. Available at: http://landworkersalliance.org.uk/wp-content/uploads/2013/01/Feeding-the-Future-

Landworkers-Alliance-A4-low-res.pdf, (accessed 27 May 2015) .

Levitt P and Merry SE (2009) Vernacularization on the ground: local uses of global women's rights in Peru, India, China and the United States. Global Networks 9(4): 441461.

Loera NA (2010) 'Encampment time': an anthropological analysis of the land occupations in Brazil. Journal of Peasant Studies 37(2): 285-318

Martínez-Torres E and Rosset P (2010) La Vía Campesina : the birth and evolution of a transnational social movement. Journal of Peasant Studies 37(1): 149-175.

Martínez-Torres E and Rosset P (2014) Diálogo de sabares in La Via Campesina: food sovereignty and agroecology. Journal of Peasant Studies 41(6): 979-997

Mignolo W (2000) Local Histories/Global Designs, Oxford: Princeton University Press

Mignolo W (2007) Coloniality: the darker side of modernity, Cultural Studies 21(2-3): 155-

167

Mujica RA and Meza MC (2009) Women's rights in Peru, Global Networks 9(4): 485-506.

Purwanto H (2013) Local to global: how Serikat Petani Indonesia has accelerated the movement for agrarian reform. In La Via Campesina 's Open Book: Celebrating 20 Years of Struggle and Hope, Harare: Vía Campesina, 1-12.

Quijano A (2000) Coloniality of power, eurocentrism, and Latin America, Neplanta: Views from South 1(3): 533-580

Reclaim the Fields (2015) Bulletin 9.Available at: http://reclaimthefields.org/sites/default/files/EN9bookletduplex.pdf, (accessed 27 May 2015).

ROPPA and Vía Campesina (2001) Joint Press Release. Available at http://viacampesina.org/en/index.php/main-issues-mainmenu-27/food-sovereignty-and-trademainmenu-38/399-joint-press-release-roppa-via-campesina (accessed 29 July 2015)

Rosset P. Re-thinking agrarian reform, land and territory in La Vía Campesina . Journal of Peasant Studies 40(4): 721-775

Sabaratnam M (2011) IR in dialogue. But can we change the subjects? A typology of decolonising strategies for the study of world politics, Millennium 39(3): 781-803

Sabaratnam M (2013) Avatars of Eurocentrism in the critique of the liberal peace, Security Dialogue 44(3): 259-278

Santos BDS, Nunes JA and Meneses MP (2007) Introduction in Santos BDS (2007) Another Knowledge is Possible: Beyond Northern Epistemologies, London: Verso, xix-lxii

Scoones I, Hall R, Borras SM Jr., White B and Wolford W (2013) The Politics of evidence: methodologies for understanding the global land rush', Journal of Peasant Studies 40(3): 469-483

United Nations (2015) Draft UN declaration on the Rights of Peasants and Other People Working in Rural Areas: Advanced Version, 27/1/2015. Available at: http://www.ohchr.org/EN/HRBodies/HRC/RuralAreas/Pages/2ndSession.aspx (accessed 30 May 2015).

Valente FLS (2014) Towards the full realization of the human right to adequate food and nutrition. Right to Food Journal: FIAN International 9(1): 2-7

Vergara-Camus L (2009) The Politics of the MST, Latin American Perspectives 36(4): 178191. 
Vía Campesina (1996) Food sovereignty: a future without hunger. Available at: http://www.voiceoftheturtle.org/library/1996\%20Declaration\%20of\%20Food\%20Sovereignt y.pdf (accessed 27 May 2015).

Vía Campesina (2007) Nyéléni declaration on food sovereignty. Journal of Peasant Studies 36(3): 673-676.

Vía Campesina (2009) Small scale sustainable farmers are cooling down the earth. Available at: http://viacampesina.org/downloads/pdf/en/EN-paper5.pdf, 2009 (accessed 27 May 2015).

Vía Campesina (2011a) What is la Vía Campesina ? Available at http://viacampesina.org/en/index.php/organisation-mainmenu-44/what-is-la-via-campesinamainmenu-45 (accessed 27 May 2015).

Vía Campesina (2011b) Declaration of rights of peasants - women and men. Available at: http://viacampesina.org/en/index.php/publications-mainmenu-30/1016-declaration-of-rightsof-peasants-women-and-men (accessed 27 May 2015).

Vía Campesina (2013) Gaining support for the peasant's way. Available at: http://viacampesina.org/en/index.php/main-issues-mainmenu-27/food-sovereignty-and-trademainmenu-38/1501-gaining-support-for-the-peasant-s-way-la-via-campesina-at-un-s-leadingfood-security-institutions (accessed 27 May 2015).

Vía Campesina (2014a) Global peasant movement exemplifies power of organized humanity. Available at: http://viacampesina.org/en/index.php/actions-and-events-mainmenu-26/17april--day-of-peasants-struggle-mainmenu-33/1592-global-peasant-movement-exemplifiespower-of-organized-humanity (accessed 26 May 2015).

Vía Campesina (2014b) Report of the VI international conference. Available at: http://viacampesina.org/downloads/pdf/en/EN-VITHCONF-2014.pdf, (accessed 1 June 2015). Vía Campesina (2015) UN concludes second session for declaration on peasants rights. Available at: http://viacampesina.org/en/index.php/main-issues-mainmenu-27/human-rightsmainmenu-40/peasants-right-resources/1741-un-concludes-the-2nd-session-for-declarationon-the-rights-of-peasants-and-other-people-working-in-rural-areas, (accessed 27 May 2015).

Walsh C (2010) Development as Beun Vivir: institutional arrangements and (de)colonial entanglements. Development 53(1): 15-21

White B, Borras SM Jr., Hall R, Scoones I and Wolford W (2012) The New Enclosures. Journal of Peasant Studies 39(3-4): 619-647.

Windfuhr M and Jonsén J (2005) Food Sovereignty: Towards Democracy in Localized Food Systems. Rugby: FIAN international, ITDG Publishing.

Wittman H (2009) Interview with Paul Nicholson. Journal of Peasant Studies 36:3: 676-682.

Wolford W (2004) This land is ours now: spatial imaginaries and the struggle for land in Brazil. Annals of the Association of American geographers 94(2): 409-424

Wolford W (2005) Agrarian moral economies and neoliberalism in Brazil. Environment and Planning A 37(2): 241-261

Zeigler J, Golay C, Mahon C, Way S-A (2011) The Fight for the Right to Food: Lessons Learned, Geneva: Palgrave MacMillan

Zwingel S (2012) How do norms travel? Theorizing international women's rights in transnational perspective. International Studies Quarterly 56(1): 115-129. 
i UN doc. A/HRC/25/57, para 7

ii UN doc. A/HRC/25/57 para 7

iii UN doc. A/HRC/25/57

iv UN doc. E/CN.4/2004/10, para 33

'UN doc. E/CN.4/2004/10, para 54

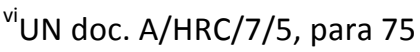

vii UN doc. $A / 65 / 281$

viii UN doc. $A / 64 / 170$

${ }^{\text {ix }}$ See also UN doc.A/HRC/16/49

${ }^{x}$ UN doc. A/HRC/25/57 para 26; 50

${ }^{x i}$ UN doc. A/HRC/WG.15/1/2

xii UN doc. $A / H R C / 19 / 75$

xiii UN doc. $A / H R C / R E S / 21 / 19$

${ }^{\text {xiv } U N ~ d o c . ~} A / H R C / R E S / 21 / 19$

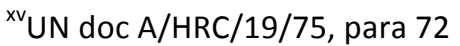

xvi UN doc. A/HRC/WG.15/1/2, my emphasis

xvii Ireland, on behalf of the EU. Available at:

http://www.ohchr.org/EN/HRBodies/HRC/RuralAreas/Pages/FirstSessionStatements.aspx, (accessed 27 May 2015)

xviii UN doc. A/RES/60/251

${ }^{\text {xix }} \mathrm{A} / \mathrm{HRC} / \mathrm{RES} / 5 / 1$, rule 20

${ }^{x x}$ UN doc. $A / H R C / 26 / 48$

${ }^{x x i}$ UN doc. A/HRC/RES/26/26

xxii $\mathrm{A} / \mathrm{HRC} / 26 / \mathrm{L} .13$ Vote Item: $5-39^{\text {th }}$ meeting $26^{\text {th }}$ regular session UNHRC 